\title{
Geomorphologic Model of Gunungsewu Karst, Gunung Kidul Regency, Yogyakarta Special Territory, Indonesia: The Role of Lithologic Variation and Geologic Structure
}

\author{
Sari Bahagiarti Kusumayudha, Jatmiko Setiawan, Ayu N. Ciptahening and Prabawa Dwi Septianta \\ Department of Geology, Universitas Pembangunan Nasional “Veteran” Yogyakarta, Condongcatur, DIY 55283, Indonesia
}

\begin{abstract}
Gunungsewu is a karst terrain that shows unique geomorphologic phenomena. The area is mainly composed of limestone of Wonosari Formation. Interaction of tectonic, erosion, denudation, and deposition occurred since Miocene period brings about diversity of landforms that supporting the development of this area as a natural laboratory, specific interest, scientific and educational tourisms. In general the geomorphology of Gunungsewu can be classified into two groups of landforms, the first is positive relief and the second is negative relief. The positive relief includes hills of conical, dome, convex-cone, convex and ridge. The negative relief involves cave, shaft, doline, uvala, locva and polje. This diversity is influenced by variation of physical properties of rock composing the landforms, such as hardness, internal friction angle, and geologic structures including thickness and position of bedding plane as well as joint pattern.
\end{abstract}

Key words: Geomorphology, karst, rock properties, geologic structures.

\section{Introduction}

Gunungsewu is very famous in Indonesia, especially in Java Island, as a karst terrain that is geologically, geomorphologically and hydrogeologically shows unique phenomena. Geology of Gunungsewu expresses tracks of tectonic, erosion, denudation, and deposition occurred since Miocene epoch. These processes brought about morphologic diversities that support for the development of this area as natural laboratory, special interest, scientific, and education tourisms. Therefore Gunungsewu is very potential to be promoted as an international level of geopark [1].

Gunungsewu displays a specific Tropical landform, characterized by the existence of hills, closed depressions, and caves. Although morphology of Gunungsewu area is as an ordinary karst landforms, but there is a diversity. The diversity seems to be reflecting the occurrence of various geologic factors influencing

Corresponding author: Sari Bahagiarti Kusumayudha, professor, research fields: geology and hydrogeology. E-mail: saribk@upnyk.ac.id. the landform process.

It is interpreted that the morphology is influenced by variation of physical properties of the lithology and the existing geologic structures. This hypothetical view has to be verified. In relation to that, such an assessment is needed to be done. Therefore, this study is aimed to identify geologic factors that role in the formation of karst morphology of the Gunungsewu, and develop a geomorphologic model of this area.

The study area is located in Gunungsewu karst area of Yogyakarta Special Territory, Indonesia, geographically lies of $7^{\circ} 57^{\prime}-8^{\circ} 14^{\prime}$ south latitude, and $110^{\circ} 19^{\prime}-110^{\circ} 50^{\prime}$ east longitude, about $25 \mathrm{~km}$ southeastern of Yogyakarta city. Case study was especially taken in the Ponjong and Karangmojo districts, Gunung Kidul Regency, on the coordinate of $468,750 \mathrm{mE}-473,750 \mathrm{mE}$ and $9,117,000$ $\mathrm{mN}-9,122,000 \mathrm{mN}$. Fig. 1 shows the location of the study area that can be reached easily by cars from Yogyakarta city. 

Indonesia: The Role of Lithologic Variation and Geologic Structure

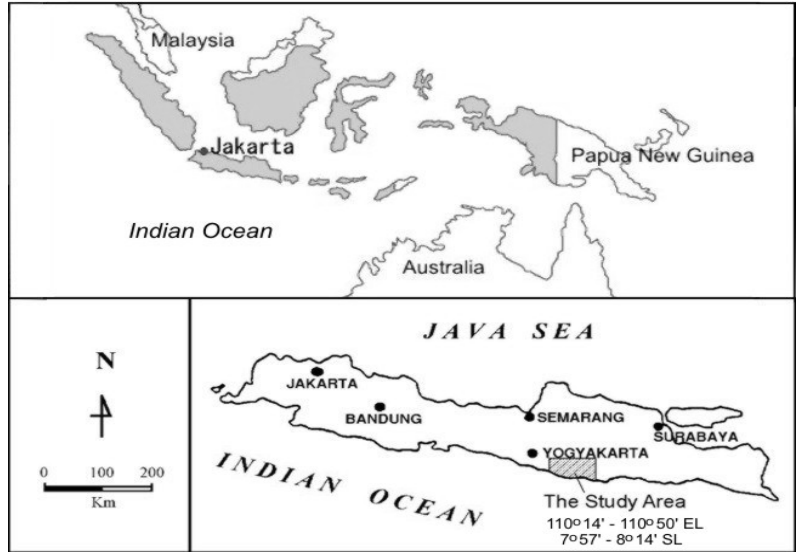

Fig. 1 Map showing the location of the study area.

\section{Methods of Study}

Approach method applied in the study was field surveying, surface geologic and geomorphologic mapping, topographic interpretation, remote sensing, petrologic and geologic structure assessment. Data used for the analyses were derived from field surveys and mapping, and from existing previous studies. Remote sensing method was run by using airphotoes of $1: 35,000$ scale and satellite images (Ers and Google Earth).

Survey and mapping were done to identify variation physical characteristics and distribution of the lithology. Geologic structure identification and measurements were operated for strike and dip and also shape of karst morphology such as hill, ridge, and valleys. Topographic and image interpretation were utilized for determining pattern and orientation of fracture system (joint, fractures, fault) also hills and valleys lineaments.

\section{Geology}

Geologic setting of Gunungsewu belongs to western part of Southern Mountains [2]. The stratigraphy from the oldest to the youngest is composed of Semilir formation, Nglanggran formation, Sambipitu formation, Oya formation, Wonosari formation, Kepek formation, and locally Terrarosa deposit.

Semilir formation belongs to deep sea sedimentary rocks consists of sandstone, tuff, tuffaceous sandstone, lapilli, tuff breccias, lappilli breccias, agglomerate, andesitic breccias, clay stone, siltstone, and shale of Oligocene-Early Miocene [3]. Semilir formation is overlain by Nglanggeran formation, consists of andesitic breccias, agglomerate, polymixed breccias, lava deposits, sandstone and tufaceous sandstone. Age of the formation is oligomiocene to Middle Miocene [3]. Nglanggeran formation is conformably overlain by sambipitu formation that comprises marl, claystone, calcareous siltstone, calcareous sandstone and tuffaceous sandstone. Sambipitu formation is Middle Miocene age [3]. Oya formation conformably overlays Sambipitu formation. This rock unit consists of calcarenite, bedded limestone, calcareous sandstone and tuffaceous-calcareous sandstone. Age of the formation is Middle Miocene to Mio-Pliocene [4]. Oya formation is overlain by Wonosari formation that consists of reef, massive and bedded limestones of Middle Miocene to Pliocene age [4]. Kepek formation consists of marl and calcarenite that lays over the Wonosari formation of Pliocene-Pleistocene epoch [4]. The geologic map of the study area is shown in Fig. 2.

Gunungsewu has been uplifted and a little bit folded since middle miocene or about 6 million years ago [3]. There is a syncline expresses as the Wonosari plateau with axial orientation of $\mathrm{N} 75^{\circ} \mathrm{E}-\mathrm{N} 255^{\circ} \mathrm{E}$, dipping no more than $10^{\circ}$, while the hills display homoclinal dipping $5^{\circ}$ to $15^{\circ}$ relatively southward $[4,5]$. In the Ponjong and Karangmojo areas, dip of the bedding planes reaches $18^{\circ}$.

Patterns of fault, joints, and fissures that is mapped by using Earth Resource Satelite, generally shows northwest-southeast direction [5, 6]. On the other hand, the general dip direction is to southwest, southeast, and south [4, 7], while the joint patterns shows northwest-southeast and northeast-southwest.

\section{Karst Geomorphology}

There are some requirements to form such a perfect karst, this include the existence of limestone of $>200 \mathrm{~m}$ thickness, massive but jointed, and bedded [8]. There 

Indonesia: The Role of Lithologic Variation and Geologic Structure

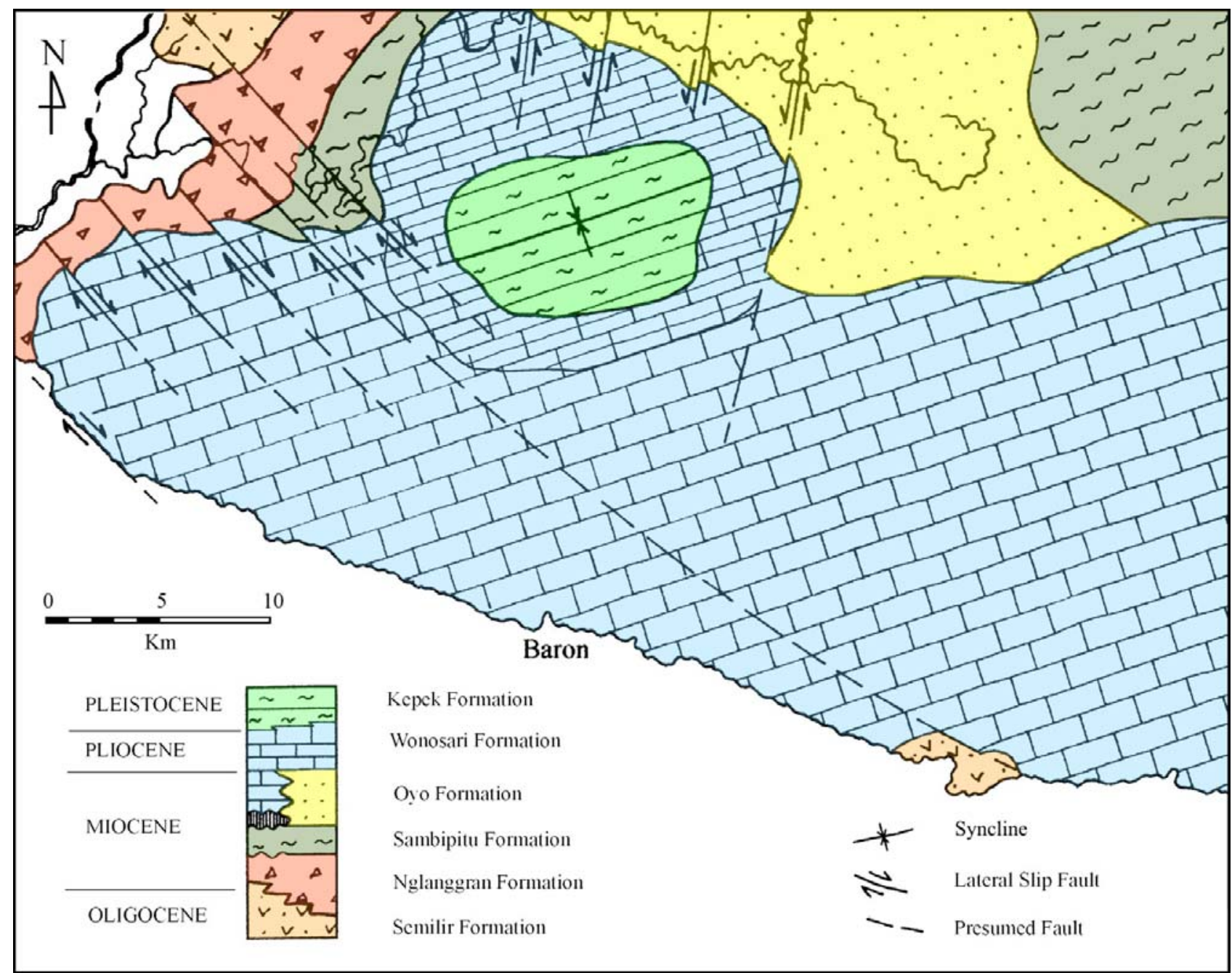

Fig. 2 Geologic map of Gunungsewu area $[5,6]$.

must be valleys that the elevation is lower than the position of the limestone. Karstification also needs warm climate, high enough rainfall (> $2000 \mathrm{~mm} /$ year); and relatively slow tectonic activity (uplifting) involving all of the area [9].

Beside the requirements mentioned above, morphologic diversity of karst is influenced by physical characteristics of the limestone, including strength and hardness [10]. Joints, cracks, faults and bedding planes are factors that contribute in karstification process [11], into which dissolution occurs.

All of the Gunungsewu area spreading is about 1,500 $\mathrm{km}^{2}$. Based on air photo interpretation, there are more or less 45.000 hills [4], with various shapes, such as cone, dome, convex and ridge (Figs. 3-6). The negative reliefs include doline, uvala, locva, polje, shaft and cave.

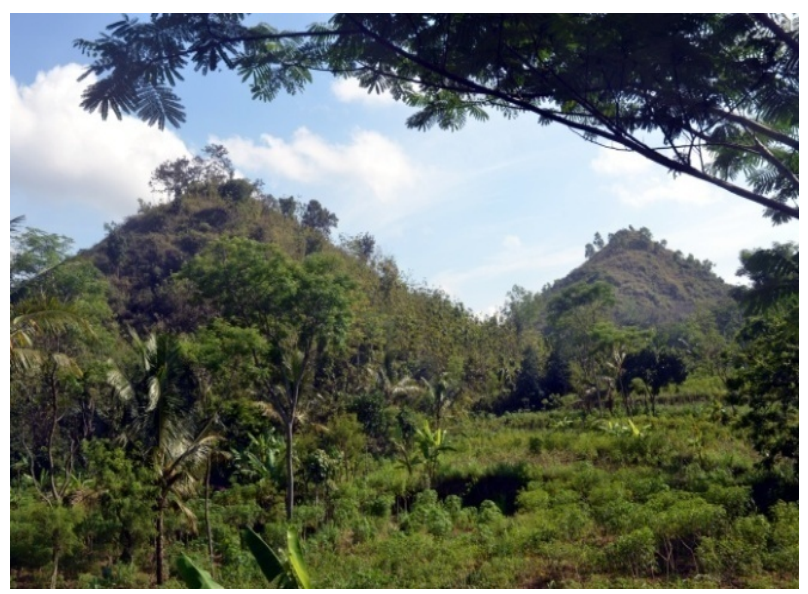

Fig. 3 Cone karst. 

Indonesia: The Role of Lithologic Variation and Geologic Structure

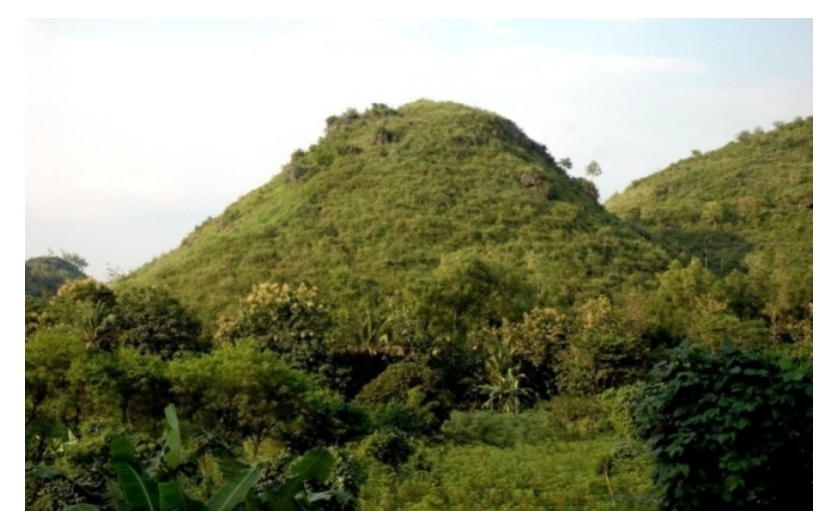

Fig. 4 Convex cone karst.

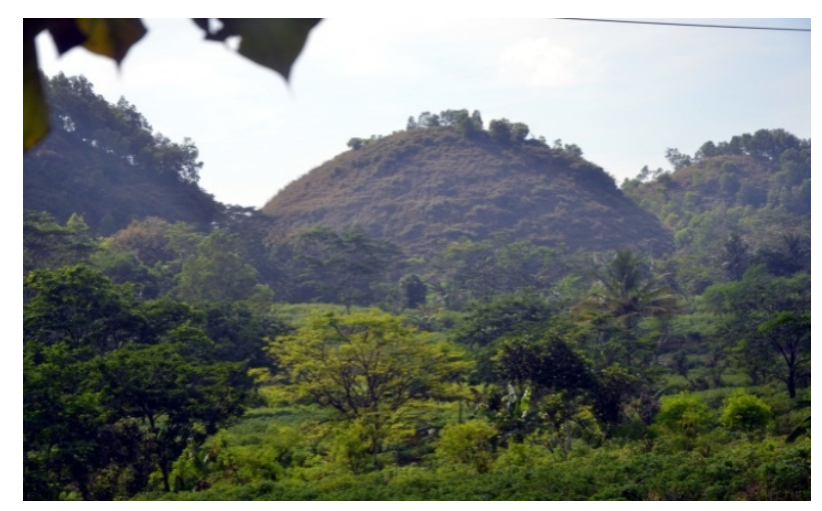

Fig. 5 Dome karst.

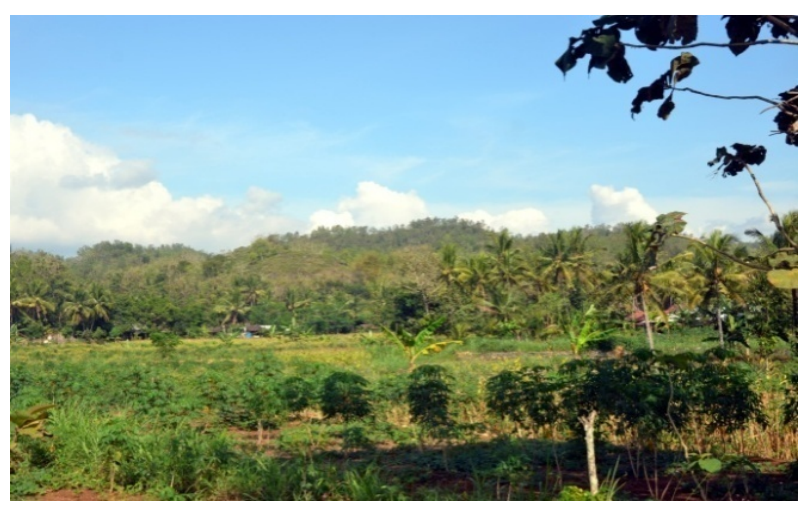

Fig. 6 Ridge karst.

\section{Influence of Lithologic Variation and Geologic Structure}

Limestone of Wonosari Formation in the Gunungsewu Area is composed of some lithofacieses, such as bedded limestone consist of packstone and wackestone, and reef limestone or boundstone [4-6]. Beside wackestone, packstone and boundstone, there is also grainstone [12]. The limestone physically shows karstification or hard and cavernous and calcification (chalky limestone), weak or brittle. If such limestones is uplifted and exposed in the area with wet tropical climate, karstification will happen. But when the limestone is exposed in an arid with a few rainfall condition, calcification will occur [13]. The sequence of caliche consists of hardpan, platty caliche, nodular caliche and chalky caliche. [14].

In this study, result of geomorphologic and geologic mapping on the distribution and variation of lithology and geologic structure verifies that different physical characteristic of lithology forms different shape of morphology, either positive or negative reliefs. In this case, internal friction angle $(\varphi)$ of limestone has an important role in producing the slope of morphology of the karst. Table 1 contains various values of internal friction angle of limestone from some sources.

The orientation of geologic structures especially joint, fault, and fissures control the lineaments of hills, valleys, that are Northwest-Southeast and Northeast-Southwest [15, 16]. The dip of bedding plane influences morphologic dimension. Table 2 displays orientations of joint patterns and hills or valleys lineaments.

\section{Karst Geomorphologic Model of Gunungsewu}

Karst geomorphology modeling of the Gunungsewu area, comprises some aspecs including morphographic morphometric, and morphogenesis [17]. Morphogenesis involves passive morphostructure, physical properties of the lithology, active morphostructure

Table 1 Values of internal friction angle $(\varphi)$ of karstic limestone and caliche [10, 18-20].

\begin{tabular}{lll}
\hline Limestone $\left({ }^{\circ}\right)$ & Dolomite, chalky limestone $\left(^{\circ}\right)$ & Source \\
\hline $33-40$ & $27-31$ & Hoek \& Bray (1981) \\
$35-50$ & 22 & Jumikis (1983) \\
$34.8-42$ & $31.5-35.5$ & Goodman (1989) \\
$32-49$ & $30-41$ & Franklin \& Dussault (1989) \\
\hline
\end{tabular}



Indonesia: The Role of Lithologic Variation and Geologic Structure

Table 2 Orientations of joint pattern, hills and valleys lineaments.

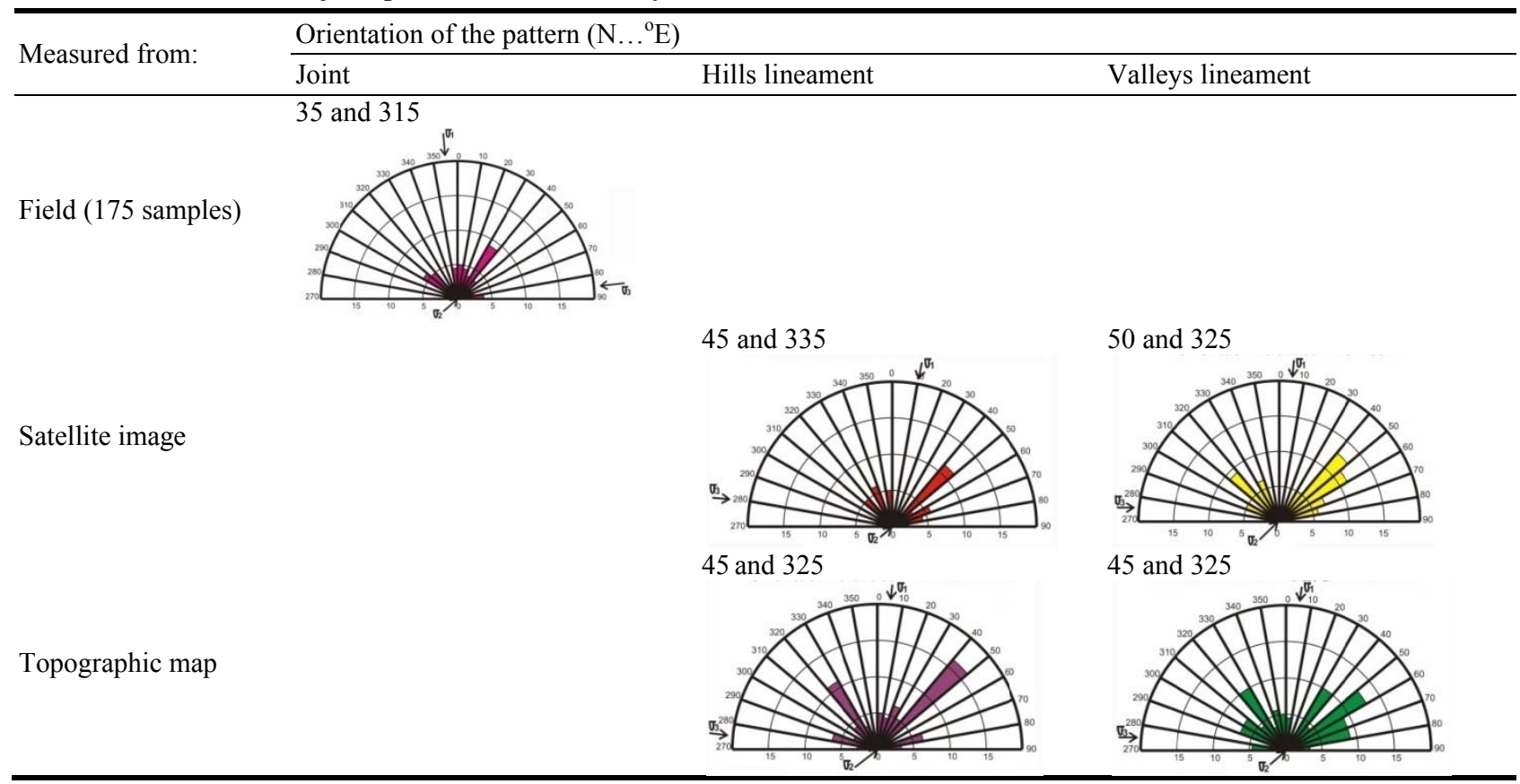

Table 3 Model of the influence of lithologic physical properties and geologic structures to positive relief karst morphology.

\begin{tabular}{|c|c|c|c|c|c|}
\hline & \multicolumn{2}{|c|}{ Morphology } & \multicolumn{3}{|c|}{ Morphogenesis } \\
\hline Lithology & Morphographic & Morphometric & $\begin{array}{l}\text { Active } \\
\text { morphostructure } \\
\text { (geologic structures) }\end{array}$ & $\begin{array}{l}\text { Passive } \\
\text { morphostructure } \\
\text { (physical properties) }\end{array}$ & $\begin{array}{l}\text { Morphodynamic } \\
\text { (exogenic } \\
\text { processes) }\end{array}$ \\
\hline $\begin{array}{l}\text { Dominated by } \\
\text { bedded } \\
\text { limestone, } \\
\text { grainstone and } \\
\text { packstone }\end{array}$ & $\mathrm{Col}$ & $\begin{array}{l}\text {-Steep slope } \\
\text {-Slope: } 30^{\circ}-45^{\circ} \\
\text {-Relatively top sharp } \\
\text {-Height: } 30-90 \mathrm{~m}\end{array}$ & $\begin{array}{l}\text {-Joint } \\
\text {-Thin bedded: }<1 \mathrm{~m} \\
\text {-Bedding plane } \\
\text { inclination: }>5^{\circ}\end{array}$ & $\begin{array}{l}\text { hard, cavernous, } \\
\text { lapies, } \\
\varphi=32-50\end{array}$ & Karstification \\
\hline $\begin{array}{l}\text { Dominated by } \\
\text { reef limestone, } \\
\text { boundstone }\end{array}$ & Cons & $\begin{array}{l}\text {-Steep slope } \\
\text {-Slope: } 35^{\circ}-45^{\circ} \\
\text {-Top convex } \\
\text {-Height: } 30-70 \mathrm{~m}\end{array}$ & $\begin{array}{l}\text {-Joint } \\
\text {-Massive, or thick } \\
\text { bedded: }>1 \mathrm{~m} \\
\text {-Bedding plane } \\
\text { inclination }>5^{\circ}\end{array}$ & $\begin{array}{l}\text { hard, cavernous, } \\
\text { lapies, } \\
\varphi=32-50\end{array}$ & Karstification \\
\hline $\begin{array}{l}\text { Caliche } \\
\text { limestone, } \\
\text { wackestone }\end{array}$ & Dome (Sigmoid & $\begin{array}{l}\text {-Steep slope } \\
\text {-Slope: } 30^{\circ}-45^{\circ} \\
\text {-Height: } 20-50 \mathrm{~m}\end{array}$ & $\begin{array}{l}\text {-Joint } \\
\text {-Massive or bedded } \\
\text {-Relatively horizontal } \\
\text { bedding plane: }<5^{\circ}\end{array}$ & $\begin{array}{l}\text { hard, cavernous, } \\
\text { lapies, } \\
\varphi=32-50\end{array}$ & $\begin{array}{l}\text { Karstification } \\
\text { Calichification }\end{array}$ \\
\hline $\begin{array}{l}\text { Caliche } \\
\text { limestone, } \\
\text { wackestone }\end{array}$ & Convex & $\begin{array}{l}\text {-Gentle slope } \\
\text {-Slope: } 12^{\circ}-20^{\circ} \\
\text {-Height: } 10-30 \mathrm{~m}\end{array}$ & $\begin{array}{l}\text {-Joint } \\
\text {-With or without } \\
\text { bedding plane } \\
\text {-Relatively horizontal } \\
\text { bedding plane: }<5^{\circ}\end{array}$ & $\begin{array}{l}\text { weak, chalky, } \\
\text { uncavernous } \\
\varphi=17-31\end{array}$ & Calichification \\
\hline $\begin{array}{l}\text { Bedded } \\
\text { limestone, } \\
\text { caliche } \\
\text { limestone }\end{array}$ & Ridge & $\begin{array}{l}\text {-Moderately inclined } \\
\text {-To steep slope } \\
\text {-Slope: } 20^{\circ}-35^{\circ} \\
\text {-Top plane } \\
\text {-Height: } 10-30 \mathrm{~m}\end{array}$ & $\begin{array}{l}\text {-Joint } \\
\text {-Thin bedded: }<1 \mathrm{~m} \\
\text {-Relatively } \\
\text { horizontal: }<5^{\circ}\end{array}$ & $\begin{array}{l}\text { hard, cavernous, } \\
\text { lapies, } \\
\varphi=32-50 \\
\text { Weak, chalky, } \\
\text { uncavernous } \\
\varphi=17-31\end{array}$ & $\begin{array}{l}\text { Karstification } \\
\text { Calichification }\end{array}$ \\
\hline
\end{tabular}



Indonesia: The Role of Lithologic Variation and Geologic Structure

Table 4 Model of the influence of lithologic physical properties and geologic structures to negative relief karst morphology.

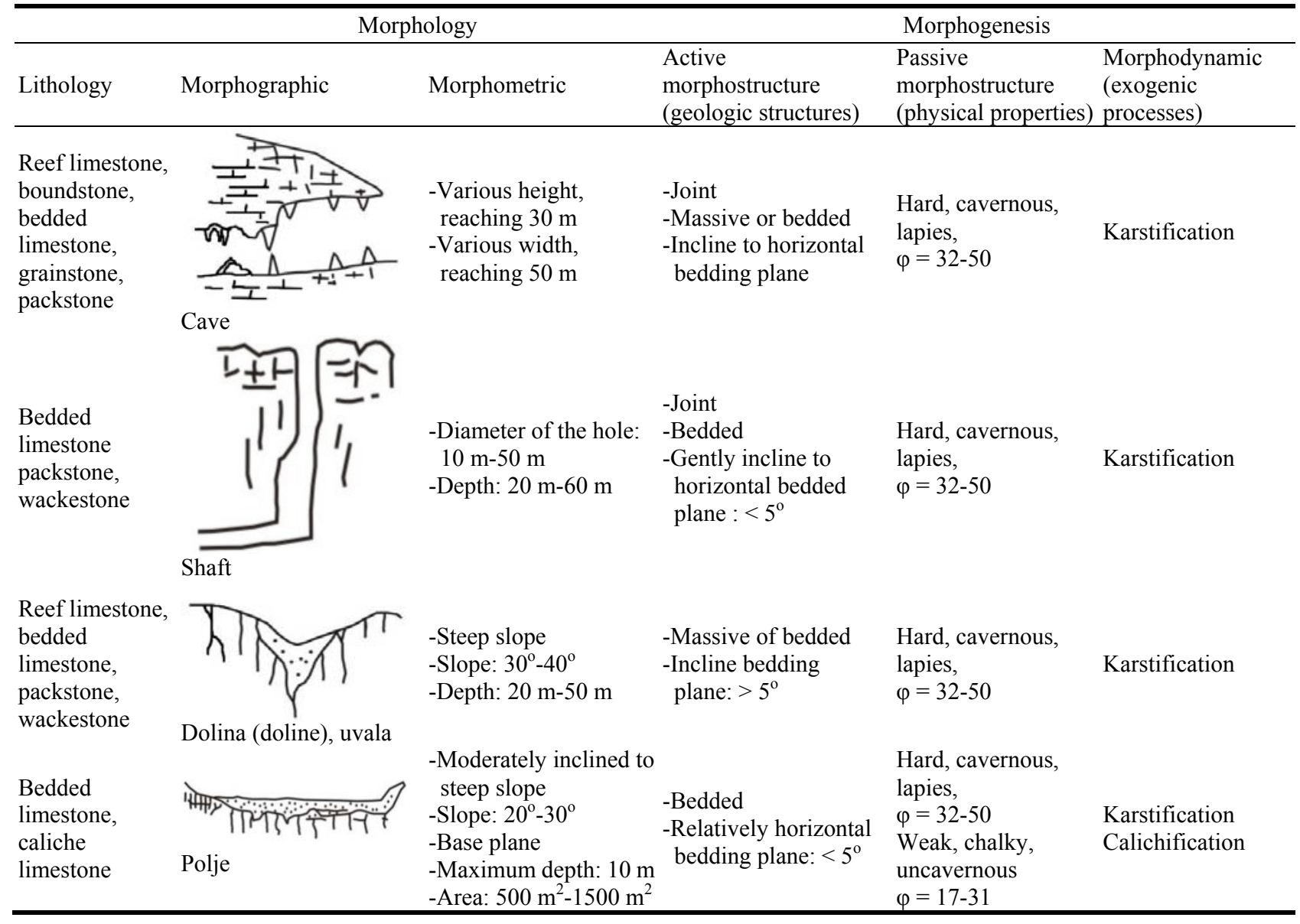

including tectonic, and morphodynamic. It is also related to exogenic processes such as erosion, dissolution, and mass wasting.

Geomorphologic diversity of Gunungsewu area involves positive and negative reliefs. Positive relief comprises hills of $10 \mathrm{~m}$ to $90 \mathrm{~m}$ height. The shape varies from conical (angular top cone), dome, rounded top cone (convex-cone), convex, and ridge. While negative reliefs include doline, uvala, polje, and shaft, or cave.

Attractive morphology is not only found on the surface, but also in subsurface or in caves. There are various ornaments such as stalactite, stalagmite, pilar, sinter, and flowstones. The formation of endokarst in the caves is also influenced by the existence of fracture structures and bedding planes. The stalactites are always found in longitudinal raw following strike of fractures that is crosscutting the wall or roof of the cave.

Tables 3-4 describe the model of karst morphology of Gunungsewu area. As already discussed above, it is controlled by variation of physical properties of the lithology and the existence of geologic structures.

\section{Conclusions}

Results of this study and analyses on the geomorphology of Gunungsewu Area conclude that:

Karst morphology of Gunungsewu area can be grouped into morphology with positive relief including hills of cone, convex-cone, dome, convex and ridge shapes, and morphology with negative relief such as cave, shaft, doline, uvala, locva, and polje;

The variation of karst morphology of Gunungsewu area is influenced by the variation of physical properties of the lithology such as hardness and internal friction angle, and geologic structures such as joint 


\section{Indonesia: The Role of Lithologic Variation and Geologic Structure}

orientation, and existence, position, thickness of bedding plane;

Karstic limestone either massive or bedded forms hills of cone, convex-cone and dome shaped, while caliche limestone displays convex hills. Internal friction angle $(\varphi)$ of the lithology determines the angle of slope inclination of the hills that are formed. The higher the value of friction angle $(\varphi)$, the steeper the slope of hills which are formed;

Joint, crack and fault patterns are correlated to the lineaments of hills and valleys of the Gunungsewu area. Position and thickness of bedding plane also controls the shape of the hills: thin inclined bedding plane will result cone shape, thick inclined bedding plane will result convex-cone, while gentle to horizontal bedding plane will result dome, convex, and ridge shapes;

Cave, shaft, doline, and uvala are only formed in karstic limestone, while polje can be found either in karstic or caliche limestone.

\section{Acknowledgment}

Gratefulness is dedicated to the Institute of Research and Community Service, UPN "Veteran" Yogyakarta for its support to this successful study.

\section{References}

[1] Kusumayudha, S. B. 2011. "Exploring the Prospective of Gunungsewu Area for a World Geopark." Presented at the Malaysia-Indonesia Join Geoheritage Convention, Terengganu, Malaysia.

[2] Van Bemmelen, R. W. 1949. The Geology of Indonesia. Vol IA. Hague: Martinus Nijhoff.

[3] Suyoto. 1994. "Stratigraphic Sequence of the Gunungsewu Carbonates." In Proceedings of the PIT IAGI XXIII, 19-32.

[4] Kusumayudha, S. B., 2004. Introduction of Karst Hydrogeology. Yogyakarta: Karst Study Center UPN "Veteran".

[5] Kusumayudha, S. B., Zen, M. T., Notosiswoyo, S., and
Gautama, R. S. 1999. "Hydrogeologic System of Gunungsewu Area." In Proceedings of the IAGI The 28th Annual Convention, 73-84.

[6] Kusumayudha, S. B., Zen, M. T., Notosiswoyo, S., and Gautama, R. S. 1997. "Study on the Distribution of Carbonate Rocks Based on Fractal Characteristics of the Valley Patterns and Secondary Porosity, Case: Paliyan and Surrounding Area, Gunung Kidul, DIY.” Jurnal Teknologi Mineral 4 (2):71-86.

[7] Setiawan, J., and Kusumayudha, S. B. 2011. "Groundwater System of Gunung Kendil and Umbul Ponjong as a Unique Geoheritage." Presented at the Malaysia-Indonesia Join Geoheritage Convention, Terengganu, Malaysia.

[8] White, W. B. 1988. Geomorphology and Hydrology of Karst Terrains. New York: Oxford University Press.

[9] Monroe, W. H. 1976. The Karst Landforms of Puerto Rico. Washington, DC: United State Government Printing Office.

[10] Franklin, J. A., and Dussault, M. B. 1989. Rock Engineering. McGraw, USA: McGraw Hill Publishing Company.

[11] Bogli, A. 1980. Karst Hydrology and Physical Speleology. Berlin, Germany: Springer Berlin Heidelberg.

[12] Dunham, R. J. 1962. "Classification of Carbonate Rocks According to Depositional Texture." In Classification of Carbonate Rocks, edited by W.E. Ham. AAPG Memoir.

[13] Esteban, M. 1996. Karst System from Prospect to Reservoir. Carbonate International Ltd.

[14] Moore, C. H. 1989. Carbonate Diagenesis and Porosity. Amesterdam: Elsevier.

[15] Kusumayudha, S. B. 2005. Fractal Geometry and Hydrogeology of Gunungsewu Area. Yogyakarta: Adicita Publisher.

[16] Kusumayudha, S. B. 2008. Karst: Cave, Underground River and Spring. Yogyakarta: Citra Aji Parama Publisher.

[17] Verstappen, H. Th. 1983. Applied Geomorphology. Elsevier Science Publishers.

[18] Goodman, R. E. 1989. Introduction to Rock Mechanics, 2nd ed.. Chichester: John Wiley \& Sons.

[19] Hoek, E., and Bray, J. W. 1981. Rock Slope Engineering, Revised 3rd ed. London: The Institution of Mining and Metallurgy London.

[20] Jumikis, A. R. 1983. Rock Mechanics, 2nd ed. Houston, Texas: Gulf Publishing Company. 